\title{
Eric C. Kollman
}

The historian and biographer of Theodor Körner and professor of history at Cornell College, Eric C. Kollman, died at his home in Mt. Vernon, Iowa, on November 1, 1981. Kollman was born in Vienna on March 12, 1903. A graduate of the Akademisches Gymnasium in Vienna, he studied from 1922 to 1927 at the University of Vienna, where he was awarded a Ph.D. degree in history and German studies.

Philosophically dedicated to socialism from earliest youth, Kollman was a member of the Association of Socialist Secondary School students already when he was studying at the gymnasium. Later, while at the University of Vienna, he took an active part in the Association of Socialist Students of Austria. After graduating from the university, he became a professor at the Brigittenau Federal Realgymnasium in the twentieth district of Vienna. There he became acquainted with Gusti Bienstock, the daughter of a textile goods merchant, who later became his wife.

As a teacher, Kollman retained his connections with the Association of Socialist Students. His multiplicity of interests had prompted him, while he was still a student, to extend his studies to the neighboring fields of philosophy, psychology, and pedagogy. Later he taught courses in these fields to various study groups of the Association for Socialist Students. Friends who knew him at that time say that Kollman was not a "leftist" but a thoroughgoing socialist who knew how to appropriate and make use of Marxist ideas in a dialectically consistent manner. They also emphasize the fact that Kollman was always respected, without ever giving an impression of presumption or arrogance. Beginning in 1929-1930, Kollman, who was an enthusiastic mountain climber, was also a leader of student summer colonies organized by the Association of Socialist Students. The last time he served in that capacity was in Hallein in 1932. As a member of the "Academic Legion" of the Republican Schutzbund, he more than once participated in violent debates with Nazi students in the aula of the University of Vienna, especially in 1932-1933.

The events of February, 1934, abruptly ended Kollman's political activities. From then on he could practice his profession only with certain restrictions. In 1935-1936 he even taught a full semester at the university extension center at Ottakring, a former Social Democratic educational center that was continued by the Dollfuß regime "in a new spirit." It might be interesting to note that, although he was very highly regarded as a lecturer, until then he had not come into prominence for publication in pertinent newspapers or journals.

Kollman's career was definitely interrupted by Hitler's march into Austria, which occurred on the very day of his thirty-fifth birthday. After 
several distressing interludes, including a brief imprisonment, Kollman succeeded, with the help of friends in Austria and in America, in emigrating to the United States with his family, after giving up his home and property in Döbling.

In the United States Kollman taught first at Parsons College and then at the University of Iowa. In 1944 he went to Cornell College, where he remained until he retired in 1973. During these years he was, among other things, chairman of the history department (1955-1968). After his retirement he gave numerous guest lectures in Germany and at various American universities. He was also a visiting expert for the high commissioner's office in the Federal Republic. He was awarded a Fulbright fellowship on four different occasions.

Kollman's most important publication was his book on Theodor Körner-Militär und Politik, brought out in Vienna in 1973 by the Verlag für Geschichte und Politik. Körner (1873-1957) was one of the most able staff officers of the First World War, who, out of conscience, served as military adviser to the Austrian Social Democrats during the First Republic. He was politically as much persecuted after February 12, 1934, as after Hitler marched into Austria in 1938. In the Second Republic he was first mayor of Vienna during the most difficult times (1945-1950) and then, after Karl Renner's death in 1950, Renner's successor as federal president (19511957). He was one of the most significant representatives of the Second Republic.

Only after many difficulties was Kollman able to complete this standard work, which comes to grips with the problem of the political commitment of this prominent Austrian born before the turn of the twentieth century. However, stipends from the Theodor-Körner-Stiftung as well as from, among others, the American Philosophical Society and the Social Science Research Council, and, last but not least, a sabbatical leave from Cornell College made it possible for him to finish the work in 1971.

In collecting source materials for the book on Körner, Kollman used, among many others, the resources of the Society for the History of the Working-Class Movement in Vienna and was a very welcome visitor there on numerous occasions. He made very generous remarks about the Society in comments on an article that Hans Schroth and I wrote on "The Society for the History of the Working-Class Movement," which was published on pp. 156-163 of Vol. XI (1975) of the Austrian History Yearbook. Among other things, he wrote: "That all these sources are now easily accessible... is a positive contribution to research in this area."

Not only his former students at Cornell College but also those at all institutions where he gave guest lectures remember Kollman favorably. In whatever he did he commanded respect, for he knew how to unite firmness 
with gentleness in accord with the principle "Suaviter in modo, fortiter in re."

Society for the History of the Working-Class Movement (Vienna)

ERNST K. HERLITZKA 